\title{
Motivasi Belajar Mahasiswa terhadap Efektifitas Bahan Ajar Berbasis E-Learning untuk KPB 1 di STAINBatunsangkar
}

\author{
Isra Nurmai Yenti \\ Prodi Tadris Matematika, Jurusan Tarbiyah \\ STAIN Batusangkar, Indonesia \\ Email: nurmaiyenti@yahoo.com \\ Hp: 081363382765
}

\begin{abstract}
This article discusses university students' learning motivation on the effectiveness of E-Learning Based material in the KPB 1 classes. The research was conducted to see the effectiveness of E- learning material that had been developed in KPB 1 to deal with students' learning motivation. In this pre-experimental study, all third semester students of Mathematic Tadris registered in academic year of 2012-2013 served as sample. Questionnaire on learning motivation was used to collect the data which was later analyzed through simple statistic. The research shows that students' learning motivation was not successfully improved after the implementation of E-Learning material. It suggests then that such material has not been effective in the KPB 1 learning.
\end{abstract}

Key Words: Learning Motivation, Effective, Learning Material, E-Learning

\begin{abstract}
Abstrak: Artikel ini membahas tentang motivasi belajar mahasiswa pada efektifitas bahan ajar berbasis elearning untuk perkuliahan KPB 1 berdasakan suatu penelitian. Penelitian ini bertujuan untuk melihat efektifitas dari bahan ajar berbasis e-learning yang telah dikembangkan pada perkuliahan KPB 1 dalam motivasi belajar mahasiswa. Jenis penelitian yang digunakan adalah penelitian pra eksperimen. Sampel penelitian ini adalah mahasiswa kelas B semester tiga tahun akademik 2012/2013. Instrumen penelitiannya adalah angket motivasi belajar. Data hasil angket dianalisis dengan teknik persentase. Hasil angket menunjukkan bahwa motivasi belajar mahasiswa setelah menggunakan bahan ajar berbasis e-learning masih berada pada kategori sedang dan belum efektif pada perkuliahan KPB 1.
\end{abstract}

Kata Kunci: Motivasi Belajar, Efektif, Bahan Ajar, E-Learning.

\section{PENDAHULUAN}

Tulisan ini disarikan dari penelitian yang berjudul "Kepraktisan dan Keefektifan Bahan Ajar Berbasis E-Learning untuk Mata Kuliah Kalkulus Peubah Banyak 1 (KPB 1)" (Yenti, 2012). Penelitian ini merupakan lanjutan dari penelitian "Pengembangan Bahan Ajar Berbasis E-Learning untuk Mata Kuliah Kalkulus Peubah Banyak 1" (Yenti, 2010).

Berdasarkan pengalaman selama mengajar KPB 1, diperoleh bahwa motivasi belajar mahasiswa kurang memuaskan. Mahasiswa kurang termotivasi karena tidak semua mahasiswa mampu menggambar bangun ruang dimensi tiga di kertas/papan tulis dengan baik. Padahal, mensketsa bangun ruang dimensi tiga dapat memudahkan mahasiswa dalam menentukan batas integral ketika mereka mencari volume dari bangun ruang tersebut.
Apabila mahasiswa tidak mampu menggambarnya, mahasiswa diminta untuk membayangkan gambar tersebut dengan cara memberikan ilustrasinya dalam kehidupan sehari-hari. Hal inipun tidak membantu mahasiswa dalam memahami materi karena masih abstrak bagi mahasiswa sehingga motivasi belajarnya juga belum memuaskan. Kondisi ini tampak dari aktivitas mahasiswa yang tidak mengerjakan tugas, menunggu mahasiswa lain mengerjakannya di depan kelas dan hasil belajar yang rendah.

Salah satu solusi permasalahan di atas adalah menyediakan suatu bahan ajar yang menarik bagi mahasiswa. Bahan ajar yang menyuguhkan grafik secara lebih konkrit. Penjelasan materinya menggunakan bahasa yang komunikatif dan sederhana. Oleh karena itu, dikembangkan suatu bahan ajar yang memanfaatkan komputer dalam penyajian 
materinya. Bahan ajar ini berupa slide presentasi dengan menggunakan Microsoft Powerpoint dan maple worksheet dengan menggunakan Maple 14. Maple worksheet yang dirancang ada 6 yaitu: maple untuk elipsoid, hiperboloid satu lembar, hiperboloid dua lembar, paraboloid eliptik, paraboloid hiperbolik dan kerucut eliptik. Bahan ajar ini di upload ke moodle yang diberi nama E-learning STAIN Batusangkar dengan alamat: Error! Hyperlink reference not valid.

Menurut pakar KPB 1, pendidikan matematika, dan multimedia menunjukkan bahwa bahan ajar berbasis e-learning sudah valid dari segi konstruk dan isi. Fauzan (2009: 18) mengemukakan bahwa pengembangan suatu produk harus memperhatikan beberapa quality criteria, yaitu: validity, practicalitiy/usability, dan effectiveness. Dengan demikian, bahan ajar berbasis e-learning perlu diukur keefektifannya dari berbagai hal. Salah satunya dari segi motivasi belajar mahasiswa.

\section{MOTIVASI BELAJAR}

Motivasi dan belajar adalah dua hal yang saling memperngaruhi. Untuk dapat belajar dengan baik, seseorang membutuhkan motivasi. Uno (2011:9) menyatakan motivasi merupakan suatu dorongan yang timbul oleh adanya rangsangan dari dalam dan dari luar sehingga seseorang berkeinginan untuk mengadakan perubahan tingkah laku/aktivitas tertentu lebih baik dari sebelumnya.

Motivasi belajar dapat timbul karena dua faktor, yaitu: faktor intrinsik dan ekstrinsik. Faktor intrinsik berupa hasrat dan keinginan berhasil, dorongan dan kebutuhan belajar, serta harapan dan cita-cita. Faktor ekstrinsik berupa penghargaan, lingkungan belajar yang kondusif, dan kegiatan pembelajaran yang menarik.

Suherman (2004:236) mengemukakan hal-hal yang perlu dilakukan dosen dalam memotivasi mahasiswa untuk belajar matematika sebagai berikut:

1. Memperlihatkan betapa bermanfaatnya matematika bagi kehidupan melalui contohcontoh penerapan matematika yang relevan dengan dunia keseharian mahasiswa.
2. Menggunakan teknik, metode dan pendekatan pembelajaran matematika yang tepat dan sesuai dengan karakteristik topik yang disajikan.

3. Memanfaatkan teknik, metode dan pendekatan yang bervariasi dalam pembelajaran matematika agar tidak monoton.

Sedangkan Keller (1983: 395) menyatakan bahwa ada empat kategori kondisi motivasional yang harus diperhatikan dosen dalam usaha menghasilkan perkuliahan yang menarik, bermakna dan memberikan tantangan bagi mahasiswa, yaitu: (1) minat (interest), (2) relevansi (relevance), (3) harapan (expectancy), dan (4) kepuasan (satisfaction). Keempat kondisi ini menggambarkan motivasi intrinsik dan ekstrinsik yang harus dimiliki seorang mahasiswa dalam belajar.

Minat mahasiswa dalam belajar muncul jika didorong oleh rasa ingin tahu yang tinggi. Dosen harus mampu merangsang dan memberikan perhatian untuk dapat meningkatkan keingintahuan mahasiswa terhadap materi perkuliahan yang diberikan.

Relevansi menunjukkan adanya hubungan materi perkuliahan dengan kebutuhan dan kondisi mahasiswa. Motivasi mahasiswa akan terpelihara apabila mereka menganggap apa yang dipelajari memenuhi kebutuhan pribadi atau bermanfaat dan sesuai dengan nilai yang dipegang.

Harapan seringkali dipengaruhi oleh pengalaman sukses di masa lampau. Dengan demikian, ada hubungan antara pengalaman sukses dan motivasi. Motivasi dapat menghasilkan ketekunan yang membawa keberhasilan dan selanjutnya pengalaman sukses tersebut akan memotivasi mahasiswa untuk mengerjakan tugas berikutnya.

Keberhasilan dalam mencapai suatu tujuan akan menghasilkan kepuasan dan mahasiswa akan termotivasi untuk terus berusaha mencapai tujuan yang serupa. Kepuasan karena tercapainya tujuan dipengaruhi oleh konsekwensi yang diterima, baik yang berasal dari dalam maupun dari luar diri mahasiswa tersebut. 


\section{KEEFEKTIFAN MOTIVASI BELAJAR MAHASISWA}

Kefektifan atau efektivitas adalah kata benda dari efektif. Menurut Kamus Besar Bahasa Indonesia, keefektifan berarti keberhasilan atau kemangkusan. Keefektifan yang dimaksudkan adalah keberhasilan bahan ajar berbasis e-learning dalam memecahkan masalah mahasiswa.

Nieveen (1999:127) menjelaskan with such effective materials, consistency exists between the intended and experiential curriculum and the intended and attained curriculum. Artinya, produk dikatakan efektif, apabila ada kekonsistenan antara harapan dengan pelaksanaan dan antara harapan dengan hasil yang dicapai. Keefektifan bahan ajar berbasis e-learning tercapai apabila motivasi belajar mahasiswa tinggi.

\section{METODE PENELITIAN}

Penelitian ini dilaksanakan dengan menggunakan metode pra-eksperimen. Metode pra-eksperimen belum eksperimen sungguhan karena masih terdapat variabel luar yang ikut berpengaruh terhadap terbentuknya variabel dependen. Hal ini terjadi karena tidak adanya variabel kontrol dan sampel tidak dipilih secara random (Sugiyono, 2009: 109). Desain praeksperimen yang digunakan adalah One-Shot Case Study (Sugiyono, 2009: 110).

Keefektifan bahan ajar berbasis $e$ learning diujicobakan pada 1 kelas yaitu kelas B semester tiga tahun akademik 2012/2013. Data motivasi belajar mahasiswa diperoleh dari angket (Tabel 1) yang disebarkan setelah mahasiswa belajar dengan bahan ajar berbasis $e$ learning.

Tabel 1. Angket Motivasi yang Diisi oleh Mahasiswa

\begin{tabular}{l|l|l}
\hline \multirow{2}{*}{ Pernyataan } & \multicolumn{2}{c}{$\begin{array}{c}\text { Kemungkinan } \\
\text { Jawaban }\end{array}$} \\
\cline { 2 - 3 } & Ya & Tidak \\
\hline $\begin{array}{l}\text { Saya mendownload slide power point } \\
\text { yang diberikan. }\end{array}$ & & \\
\hline Saya mendownload semua maple & & \\
\hline
\end{tabular}

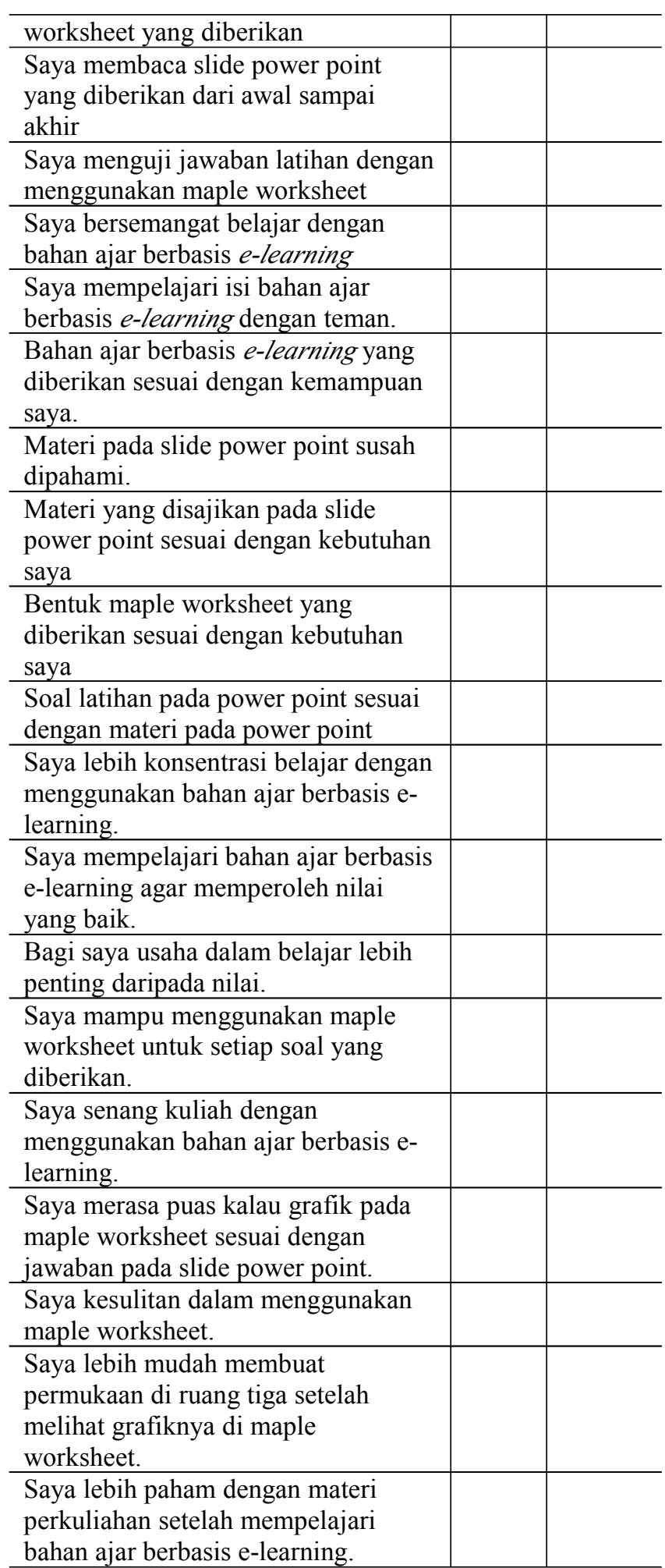

Data tersebut dianalisis dengan teknik persentase yang dinyatakan oleh Riduwan (2005:89) sebagai berikut:

Persentase $=$ $\frac{\text { jumlah skor jawaban masing - masing item }}{\text { jumlah skor idealitem }} \times 100 \%$ 
Hasil yang diperoleh diinterpretasi dengan menggunakan Tabel 2.

Tabel 2. Kriteria Interpretasi Skor Motivasi Belajar Mahasiswa

\begin{tabular}{c|c}
\hline Kriteria & Range Persentase \\
\hline Sangat rendah & $0-20$ \\
Rendah & $21-40$ \\
Sedang & $41-60$ \\
Tinggi & $61-80$ \\
Sangat tinggi & $81-100$ \\
\hline
\end{tabular}

Sumber: Riduwan (2005:89) yang telah dimodifikasi sesuai kebutuhan

\section{HASIL PENELITIAN}

Ujicoba dilakukan mulai tanggal 20 sampai dengan 27 September 2012. Mahasiswa diminta untuk mendaftar di e-learning dan mempelajari bahan tersebut. Selanjutnya mahasiswa diberi angket motivasi belajar untuk mengukur keefektifan bahan ajar berbasis $e$ learning.

Angket motivasi belajar ini diisi oleh 39 orang mahasiswa. Hasil analisis data angket motivasi untuk masing-masing indikator dapat dilihat pada Tabel 3, Tabel 4, Tabel 5 dan Tabel 6.

Tabel 3. Data Hasil Angket Motivasi Belajar Mahasiswa terhadap Minat dalam Belajar dengan Bahan Ajar Berbasis E-Learning

\begin{tabular}{|c|c|c|c|c|c|c|}
\hline \multirow{2}{*}{$\begin{array}{l}\text { Nomor } \\
\text { Item }\end{array}$} & \multicolumn{2}{|c|}{1} & \multicolumn{2}{|c|}{ ( } & \multicolumn{2}{|c|}{ Jumlah } \\
\hline & f & $\%$ & $\mathbf{F}$ & $\%$ & $\mathbf{f}$ & $\%$ \\
\hline 1 & 22 & 56,4 & 17 & 43,6 & 39 & 100 \\
\hline 2 & 17 & 43,6 & 22 & 56,4 & 39 & 100 \\
\hline 3 & 33 & 84,6 & 6 & 15,4 & 39 & 100 \\
\hline 4 & 6 & 15,4 & 33 & 84,6 & 39 & 100 \\
\hline 5 & 23 & 59 & 16 & 41 & 39 & 100 \\
\hline 6 & 27 & 69,2 & 12 & 30,8 & 39 & 100 \\
\hline \multicolumn{2}{|c|}{ Rata-rata } & \multicolumn{5}{|c|}{$54,7 \%$} \\
\hline
\end{tabular}

Berdasarkan Tabel 3 diketahui persentase terbesar terhadap minat dalam belajar dengan bahan ajar berbasis e-learning pada item nomor 3 yaitu saya membaca slide power point yang diberikan dari awal sampai akhir sebesar 84,6. Persentase terkecil pada item nomor 4 yaitu saya menguji jawaban latihan dengan menggunakan maple worksheet sebesar 15,4.
Jadi, minat mahasiswa belajar dengan bahan ajar berbasis e-learning termasuk pada kategori sedang.

Tabel 4. Data Hasil Angket Motivasi Belajar Mahasiswa terhadap Relevansi Bahan Ajar Berbasis E-Learning

\begin{tabular}{c|c|c|c|c|c|c}
\hline \multirow{2}{*}{$\begin{array}{c}\text { Nomor } \\
\text { Item }\end{array}$} & \multicolumn{2}{|c|}{$\mathbf{1}$} & \multicolumn{2}{|c|}{ ) } & Jumlah \\
\cline { 2 - 7 } & $\mathbf{f}$ & $\mathbf{\%}$ & $\mathbf{F}$ & $\mathbf{\%}$ & $\mathbf{F}$ & \% \\
\hline 7 & 17 & 43,6 & 22 & 56,4 & 39 & 100 \\
\hline 8 & 17 & 43,6 & 22 & 56,4 & 39 & 100 \\
\hline 9 & 31 & 79,5 & 8 & 20,5 & 39 & 100 \\
\hline 10 & 29 & 74,4 & 10 & 25,6 & 39 & 100 \\
\hline 11 & 36 & 92,3 & 3 & 7,7 & 39 & 100 \\
\hline \multicolumn{6}{c}{$60,68 \%$} \\
\hline
\end{tabular}

Dari Tabel 4 terlihat bahwa persentase terbesar untuk relevansi bahan ajar berbasis $e$ learning berada pada item nomor 11 yaitu soal latihan pada power point sesuai dengan materi pada power point sebesar 92,3. Persentase terkecil pada item nomor 7 dan 8 yaitu bahan ajar berbasis e-learning yang diberikan sesuai dengan kemampuan saya dan materi pada slide power point susah dipahami sebesar 43,6. Jadi, relevansi bahan ajar berbasis e-learning termasuk pada kategori tinggi.

Tabel 5. Data Hasil Angket Motivasi Belajar Mahasiswa terhadap Harapan Mahasiswa Setelah Belajar dengan Bahan Ajar Berbasis E-Learning

\begin{tabular}{c|c|c|c|c|c|c}
\hline \multirow{2}{*}{$\begin{array}{c}\text { Nomor } \\
\text { Item }\end{array}$} & \multicolumn{2}{|c|}{$\mathbf{1}$} & \multicolumn{2}{|c|}{ 0 } & Jumlah \\
\cline { 2 - 7 } & $\mathbf{f}$ & $\mathbf{\%}$ & $\mathbf{F}$ & $\mathbf{\%}$ & $\mathbf{f}$ & $\mathbf{\%}$ \\
\hline 12 & 13 & 33,3 & 26 & 66,7 & 39 & 100 \\
\hline 13 & 35 & 89,7 & 24 & 10,3 & 39 & 100 \\
\hline 14 & 39 & 100 & 0 & 0 & 39 & 100 \\
\hline 15 & 0 & 0 & 39 & 100 & 39 & 100 \\
\hline Rata-rata & \multicolumn{5}{c}{$63,2 \%$} \\
\hline
\end{tabular}

Tabel 5 memaparkan persentase terbesar harapan mahasiswa setelah belajar bahan ajar berbasis e-learning pada item nomor 14 yaitu bagi saya usaha dalam belajar lebih penting daripada nilai sebesar 100. Persentase terkecil 
pada item nomor 5 yaitu saya mampu menggunakan maple worksheet untuk setiap soal yang diberikan sebesar 0. Jadi, harapan mahasiswa setelah belajar bahan ajar berbasis $e$ learning termasuk pada kategori tinggi.

Tabel 6. Data Hasil Angket Motivasi Belajar Mahasiswa terhadap Kepuasan Menggunakan Bahan Ajar Berbasis ELearning

\begin{tabular}{c|c|c|c|c|c|c}
\hline \multirow{2}{*}{$\begin{array}{c}\text { Nomor } \\
\text { Item }\end{array}$} & \multicolumn{2}{|c|}{$\mathbf{1}$} & \multicolumn{2}{|c|}{ O } & Jumlah \\
\cline { 2 - 7 } & $\mathbf{f}$ & $\mathbf{\%}$ & $\mathbf{F}$ & $\mathbf{\%}$ & $\mathbf{f}$ & $\mathbf{\%}$ \\
\hline 16 & 26 & 66,7 & 13 & 33,3 & 39 & 100 \\
\hline 17 & 31 & 79,5 & 8 & 20,5 & 39 & 100 \\
\hline 18 & 15 & 38,5 & 24 & 61,5 & 39 & 100 \\
\hline 19 & 28 & 71,8 & 11 & 28,2 & 39 & 100 \\
\hline 20 & 23 & 59 & 16 & 41 & 39 & 100 \\
\hline
\end{tabular}

Tabel 6 menunjukkan bahwa persentase terbesar untuk kepuasan menggunakan bahan ajar berbasis e-learning berada pada item nomor 17 yaitu saya merasa puas kalau grafik pada maple worksheet sesuai dengan jawaban pada slide power point sebesar 79,5. Persentase terkecil pada item nomor 18 yaitu saya kesulitan dalam menggunakan maple worksheet sebesar 38,5. Jadi, kepuasan menggunakan bahan ajar berbasis e-learning termasuk pada kategori tinggi.

Hasil sebaran perindikator data angket motivasi belajar mahasiswa dapat dilihat pada Tabel 7.

Tabel 7. Data Sebaran Skor Hasil Angket Motivasi Belajar Mahasiswa

\begin{tabular}{c|c}
\hline Indikator & Jumlah skor \\
\hline Minat & 128 \\
\hline Relevansi & 130 \\
\hline Harapan & 87 \\
\hline Kepuasan & 123 \\
\hline Jumlah seluruh skor & 468 \\
\hline Jumlah skor ideal item & 780 \\
\hline
\end{tabular}

Tabel 7 memperlihatkan bahwa jumlah skor hasil jawaban mahasiswa terhadap angket motivasi belajar adalah 468 (60\%). Menurut
Tabel 2 kriteria interprestasi skor motivasi belajar mahasiswa diperoleh bahwa tingkat motivasi belajar mahasiswa setelah mengikuti perkuliahan dengan bahan ajar berbasis $e$ learning termasuk kategori sedang. Berdasarkan data di atas diperoleh bahwa bahan ajar berbasis e-learning belum efektif karena motivasi belajar mahasiswa masih berada pada kategori sedang.

\section{PEMBAHASAN}

Pernyataan yang terdapat dalam angket motivasi belajar dikelompokkan menjadi 4 bagian.

1. Minat dalam belajar dengan bahan ajar berbasis e-learning

Sebagian besar mahasiswa mendonwload materi slide power point yang diberikan dan sebagian besar tidak mendownload semua maple worksheet yang diberikan. Mahasiswa yang tidak mendownload materi slide power point memiliki dan mempelajari materi tersebut dengan cara memfotokopi slide dari temannya yang mendownload. Hal ini terlihat dari jawaban mereka ketika mengisi angket yaitu mereka membaca slide power point yang diberikan dari awal sampai akhir. Namun, mereka tidak menguji soal latihan yang diberikan dengan menggunakan maple worksheet. Lebih dari 50\% mahasiswa bersemangat belajar dengan e-learning dan mempelajari isi bahan ajar berbasis e-learning dengan teman.

Berdasarkan hal di atas tampak bahwa minat mahasiswa dalam belajar dengan bahan ajar berbasis e-learning masih kurang. Hal ini disebabkan mahasiswa belum terbiasa dengan e-learning. Selain itu, mahasiswa belum mampu belajar mandiri. Mahasiswa tidak menggunakan maple worksheet yang diberikan karena belum terinstall di komputer/netbook. Bagi mahasiswa yang memiliki program ini, tidak bisa mengujinya karena prosesnya yang lambat.

Jadi, kurangnya minat mahasiswa disebabkan mahasiswa tidak terbiasa, kurang berpartisipasi dan belum 
berpengalaman. Sebagaimana Sardiman (2007:7) menyatakan minat timbul tidak secara tiba-tiba/spontan, melainkan timbul akibat dari partisipasi, pengalaman, kebiasaan pada waktu belajar atau bekerja.

2. Relevansi bahan ajar berbasis e-learning

Menurut mahasiswa, bahan ajar berbasis e-learning yang diberikan belum sesuai dengan kemampuannya. Mahasiswa tidak mampu menggunakan maple yang diberikan karena program ini masih baru bagi mereka. Sedangkan materi pada slide power point susah dipahami karena mereka terbiasa belajar dari penjelasan dosen. Ketika diminta belajar sendiri, mereka tidak mampu melakukannya. Hal ini sesuai dengan data angket pada butir 6 yaitu mahasiswa mempelajari isi bahan ajar berbasis e-learning dengan teman sebesar $69,2 \%$.

Uno (2011:8) menyatakan apabila seseorang merasa yakin mampu menghadapi tantangan maka biasanya orang tersebut terdorong melakukan kegiatan tersebut. Akibat mahasiswa tidak mampu menggunakan bahan ajar dan belajar sendiri, motivasi mereka untuk kedua pernyataan tersebut adalah sedang. Dengan kata lain, mereka kurang terdorong untuk melakukan kegiatan di atas.

Sedangkan materi dan bentuk maple worksheet sudah sesuai dengan kebutuhan mahasiswa. Soal latihan yang diberikan juga sudah sesuai dengan materi pada slide. Alhasil, motivasi mahasiswa untuk pernyataan tersebut adalah tinggi dan sangat tinggi. Sebagaimana Sardiman (2007:7) menyatakan motivasi akan selalu terkait dengan kebutuhan, sebab seseorang akan terdorong melakukan sesuatu bila merasa ada suatu kebutuhan.

3. Harapan mahasiswa setelah belajar dengan bahan ajar berbasis e-learning

Pada umumnya harapan mahasiswa setelah belajar dengan bahan ajar berbasis $e$ learning adalah agar memperoleh nilai yang baik. Untuk mencapai nilai yang baik tersebut, mereka belajar dengan teman.
Namun, mereka tidak konsentrasi belajar dengan menggunakan bahan ajar berbasis $e$ learning karena mahasiwa tidak mampu menggunakan maple worksheet untuk setiap soal yang diberikan.

Dengan demikian, harapan mahasiswa setelah belajar dengan bahan ajar berbasis e-learning adalah tinggi. Mereka perlu diberikan perkuliahan tentang cara menggunakan maple sehingga bisa lebih konsentrasi dalam belajar. Konsentrasi merupakan salah satu faktor-faktor psikologis dalam belajar. Dalam konsentrasi, keterlibatan mental secara detail sangat diperlukan sehingga perhatian pada belajar tidak sekedarnya. Motivasi, dalam hal ini harapan, sangat membantu tumbuhnya proses pemusatan perhatian (Sardiman, 2007:40).

4. Kepuasan menggunakan bahan ajar berbasis e-learning

Seseorang akan termotivasi jika pekerjaan yang dilakukannya sukses. Ada beberapa cara yang dapat dilakukan guru dalam perencanaan pengajaran untuk membangkitkan belajar para siswa, salah satunya adalah memberikan kesempatan untuk sukses (Sagala, 2003:153). Begitu juga dengan mahasiswa, ia merasa puas dan semakin termotivasi jika grafik pada maple worksheet sesuai dengan jawaban pada slide power point dan lebih mudah membuat permukaan di ruang tiga setelah melihat grafiknya di maple worksheet sehingga mahasiswa senang belajar dengan bahan ajar berbasis e-learning. Keberhasilan yang dicapai mahasiswa dapat menimbulkan kepuasan dan kemudian membangkitkan motivasi (Sagala, 2003:153). Jadi, kepuasan mahasiswa dalam menggunakan bahan ajar berbasis e-learning adalah tinggi.

\section{SIMPULAN}

Kesimpulan penelitian ini adalah motivasi belajar mahasiswa masih pada kategori sedang sehingga keefektifan bahan ajar berbasis e-learning belum tercapai. Hal ini disebabkan oleh sedikitnya waktu yang diberikan kepada 
mahasiswa untuk mempelajari bahan ajar ini sehingga disarankan mahasiswa disediakan waktu yang cukup untuk memanfaatkannya. Selain itu, dosen memberikan perkuliahan tentang penggunaan Maple atau memasukkan materi Maple ke dalam mata kuliah Aplikasi Komputer sehingga mahasiswa terampil menggunakan software ini. Penelitian selanjutnya yang akan menggunakan Maple di netbook, diharapkan mencari versi baru yang lebih cepat prosesnya di netbook atau mengubahnya ke dalam Maplet.

\section{DAFTAR RUJUKAN}

Fauzan, A. 2009. Kumpulan Slide Penelitian Pengembangan. Materi Kegiatan Workshop Metodologi Penelitian Aplikatif Dosen. STAIN Batusangkar. 19, 20, dan 31 Desember 2009.

Keller, J. M. 1983. Motivational Design of Instruction. Dalam Reigeluth, Charles M. (Ed.), Instructional Design Theories and Model: An Overview of their Current Status. London: Law Rence Erldaum Associates Publishers.

Nieveen, N. 1999. Design Approaches and Tools in Education and Training. Dordrecht: Kluwer Academic Publishers.

Riduwan. 2005. Belajar Mudah Penelitian untuk Guru, Karyawan dan Peneliti Pemula. Bandung: Alfabeta.

Sagala, S. 2003. Konsep dan Makna Pembelajaran: untuk Membantu Memecahkan Problematika Belajar dan Mengajar. Bandung: CV Alfabeta.

Sardiman, A.M. 2007. Interaksi dan Motivasi Belajar Mengajar. Jakarta: PT RajaGrafindo Persada.

Sugiyono. 2009. Metode Penelitian PendidikanPendekatan Kuantitatif, Kualitatif, dan R\&D. Bandung: Alfabeta.
Suherman, E. dkk. 2004. Common TextBook Strategi Pembelajaran Matematika Kontemporer. Bandung: JICAUniversitas Pendidikan Indonesia (UPI).

Uno, H. B. 2011. Teori Motivasi dan Pengukurannya: Analisis di Bidang Pendidikan. Jakarta: Bumi Aksara.

Yenti, I. N. 2012. Kepraktisan dan Keefektifan Bahan Ajar Berbasis E-Learning untuk Mata Kuliah Kalkulus Peubah Banyak I (KPB 1). Laporan Penelitian tidak diterbitkan. Batusangkar: STAIN Batusangkar.

Yenti, I. N. 2010. Pengembangan Bahan Ajar Berbasis E-Learning untuk Mata Kuliah Kalkulus Peubah Banyak I $(K P B$ 1) di STAIN Batusangkar. Laporan Penelitian tidak diterbitkan. Batusangkar: STAIN Batusangkar. 